\title{
ANALISIS SEBARAN DAN FAKTOR PENYEBAB KEMISKINAN DI KABUPATEN BANDUNG BARAT
}

\author{
Sarah Nita Hasibuan ${ }^{1}$, Bambang Juanda ${ }^{2}$ dan Sri Mulatsih ${ }^{3}$ \\ 1)Mahasiswa Program Studi Ilmu Perencanaan Wilayah dan Perdesaan, Sekolah Pascasarjana, \\ Institut Pertanian Bogor \\ 2,3) Program Studi Ilmu Perencanaan Wilayah dan Perdesaan, Fakultas Ekonomi dan Manajemen, \\ Institut Pertanian Bogor \\ e-mail : 1)hasibuannita091@gmail.com \\ (Diterima 19 Juli 2019/Disetujui 14 Agustus 2019)
}

\begin{abstract}
Poverty is a level of life that below the minimum standard of living needs. The dominant factors that influence the emergence of poverty include education, income, location, limited access to health, finance and public services. Poverty is also one of the crucial issues in West Bandung Regency, where West Bandung Regency has the highest poverty rate compared to surrounding areas such as Bandung City, Bandung Regency, and Cimahi City. The purposes of this study are to analyze the pattern of spatial poverty distribution in general (Moran Index) and in each village (2) Analyze the factors that influence poverty in West Bandung Regency, which are carried out in 165 villages. The results of this study state that there was a positive spatial autocorrelation of 0,464173 which indicated the existence of a link between the poor population in each village and the pattern of poverty that clustered. The LISA test showed the poverty level of the population was clustered into four poverty clusters, namely 17 villages that were in the high-high criteria, 31 villages in the low-low criteria, 5 villages in the low-high criteria and 1 village in the high-low criteria. The factors that influenced poverty in West Bandung Regency were population, education level, village fund allocation, number of groceries, and village funds, while the village index builds, the distance of villages to the capital and the number of people using National electrical corporate (PLN) were not significant to reduce poverty.
\end{abstract}

Keyword: Poverty, Spatial Autocorrelation, Moran Index, Mapping cluster

\begin{abstract}
ABSTRAK
Kemiskinan merupakan suatu tingkat kehidupan yang berada dibawah standar kebutuhan hidup minimum. Faktor yang dominan yang mempengaruhi timbulnya kemiskinan diantaranya pendidikan, pendapatan, lokasi, keterbatasan akses kesehatan, keuangan dan pelayanan publik. Kemiskinan juga merupakan salah satu isu yang krusial di Kabupaten Bandung Barat, dimana Kabupaten Bandung Barat memiliki tingkat kemiskinan tertinggi dibandingkan wilayah sekitarnya seperti Kota Bandung, Kabupaten Bandung, dan Kota Cimahi. Tujuan penelitian ini adalah Menganalisis pola sebaran kemiskinan spasial secara umum (Indeks Moran) maupun pada masing-masing desa (2) Menganalisis faktor-faktor yang mempengaruhi kemiskinan di Kabupaten Bandung Barat, yang dilakukan di 165 desa. Hasil penelitian ini menyebutkan bahwa terdapat autokorelasi spasial positif sebesar 0,464173 yang menunjukkan adanya keterkaitan spasial penduduk miskin disetiap desa dengan pola kemiskinan mengelompok (clustered). Uji LISA menunjukkan tingkat kemiskinan penduduk diklasterkan kedalam empat klaster kemiskinan yakni sebanyak 17 desa yang berada pada kriteria high-high, 31 desa/kelurahan berada pada kriteria low-low, 5 desa pada kriteria low-high dan 1 desa berada pada kriteria high-low. Adapun faktor-faktor yang mempengaruhi kemiskinan di Kabupaten Bandung Barat adalah jumlah penduduk, tingkat pendidikan, alokasi dana desa (ADD), jumlah toko kelontong dan dana desa, sedangkan indeks desa membangun, jarak desa ke ibukota dan jumlah masyarakat yang menggunakan listrik PLN tidak signifikan menurunkan kemiskinan.
\end{abstract}

Kata kunci: Kemiskinan, Autokorelasi Spasial, Uji Moran, Pemetaan Cluster 


\section{PENDAHULUAN}

Pembangunan dilaksanakan guna mewujudkan kesejahteraan masyarakat melalui pengambangan ekonomi dan diharapkan mampu mengatasi permasalahan pembangunan dan sosial kemasyarakatan dan kemiskinan. Kemiskinan merupakan suatu tingkat kehidupan yang berada dibawah standar kebutuhan hidup minimum. Standar kehidupan minimum ditentukan berdasarkan kebutuhan pokok pangan dan hidup sehat yang didasarkan pada kebutuhan beras dan kebutuhan gizi (Sajogyo, 1987). Kebijakan penanggulangan kemiskinan tertuang dalam Intruksi Presiden No 15 tahun 2010 tentang Upaya Percepatan Penanggulangan Kemiskinan, yang pada intinya penanggulangan kemiskinan itu bersifat top down.

Salah satu karakteristik kemiskinan Indonesia yaitu kemiskinan di daerah perdesaan. Dimana sebagian besar penduduk miskin terdapat pada daerah perdesaan. Berdasarkan data BPS tahun 2017 menyebutkan bahwa kemiskinan di perdesaan sebesar 16,31 persen, sedangkan kemiskinan perkotaan sebesar 10,27 persen. Salah satu yang menjadi faktor penyebab tingginya angka kemiskinan tersebut karena sebagian besar penduduk desa bekerja disektor pertanian, umumnya sebagai buruh tani dan buruh kasar, sehingga pendapatan masyarakat sangat rendah. Menurut Kotze (dalam Hikmat, 2004) mengemukakan rata-rata masyarakat miskin menetap di wilayah yang terisolasi seperti perdesaan.

Undang- Undang Nomor 23 Tahun 2014 tentang pemerintah daerah, yang seharusnya mampu memeratakan pembangunan, akan tetapi belum berdampak pada kehidupan ekonomi masyarakat desa. Hal ini dibuktikan dengan tingginya angka kemiskinan di desa yang menyebabkan migrasi penduduk ke kota. Sejalan dengan penelitian Nugraha dan Sari (2016) tingkat kemiskinan yang tinggi di perdesaan menyebabkan migrasi penduduk ke kota, akibatnya kota dan pusat-pusat pertumbuhan menjadi tidak efisien dan lemah dalam memberikan pelayanan pada masyarakat. Dengan demikian desa menjadi tertinggalkan dan tidak berkembang.
Nasution (2008) mangatakan faktor yang dominan yang mempengaruhi timbulnya kemiskinan diantaranya pendidikan, pendapatan, lokasi, keterbatasan akses kesehatan, keuangan dan pelayanan publik. Lokasi merupakan salah satu dimensi ruang, sehingga secara langsung mempengaruhi kemiskinan.

Permasalahan kemiskinan juga merupakan salah satu isu strategis di Kabupaten Bandung Barat Provinsi Jawa Barat. Adapun Angka kemiskinan pada tahun 2017 sebesar 11,45 persen, tetapi laju penurunannya masih sangat lambat. Persentase penduduk miskin dari tahun 2013-2017 secara berturut-turut adalah $11,25 \%, 12,26 \%, 12,67 \%, 11,76 \%$, dan 11,45\% (BPS Kab. Bandung Barat 2019). Berdasarkan data tersebut menunjukkan bahwa kemiskinan di Kabupaten Bandung Barat cenderung fluktuatif meskipun perbaikan program anti kemiskinan telah pemerintah lakukan, namun pada kenyataannya masih meninggalkan permasalahan baik dalam skala nasional maupun lokal. Jika dilihat dari angka gini rasio Kabupaten Bandung Barat menunjukkan laju penurunan yang tidak konsisten, berikut secara berturut - turut dari tahun 2013-2017 adalah 0.31, 0.32, 0.34, 0.35 dan 40.5 (Kab. Bandung Barat 2019).

Thaib (2008), Syafitri et al. (2008) dan Rustiadi et al. (2009) berdasarkan hasil penelitiannya mengemukakan bahwa program pembangunan khususnya dalam penanggulangan kemiskinan harus memperhatikan unsur spasial atau lokasi sehingga kegagalan program ataupun kebijakan dapat diminimalisir. Selain pola spasial, yang perlu diperhatikan dalam penanggulangan kemiskinan adalah ketersediaan aset dan ketersediaan sarana prasarana pendukung dan kualitas sumberdaya manusia.

Apabila dibandingkan dengan daerah di sekitarnya Kabupaten Bandung Barat merupakan salah satu kabupaten dengan penduduk miskin paling besar yakni 11, 49 persen, Kabupaten Bandung 7,36 persen, Kota Bandung (4,17 persen) dan Kota Cimahi (5,76 persen) sebagai kabupaten/kota terdekat bahkan angka kemiskinannya bahkan lebih tinggi jika dibandingkan dengan Provinsi Jawa Barat yang hanya sebesar 8,71 persen (BPS Kab. Bandung Barat, 2019). Tingginya angka 
tersebut diharapkan ini menjadi perhatian serius oleh pemerintah Kabupaten Bandung Barat untuk mensejahterakan masyarakatnya. Jika dilihat dari aspek jarak Kabupaten Bandung Barat memiliki lokasi yang lebih dekat dengan Kota Bandung yang merupakan salah satu pusat pertumbuhan ekonomi di Jawa Barat.

Menurut data BPS 2019 Sektor utama penggerak pertumbuhan ekonomi di Kabupaten Bandung Barat adalah industri pengolahan sebesar 39,78 persen, perdagangan besar dan eceran, reparasi mobil dan sepeda motor sebesar 14,45 persen dan sektor pertanian, kehutanan dan perikanan sebesar 13,15 persen. Tingginya angka tersebut belum mampu mereduksi kemiskinan di Kabupaten Bandung Barat. Dengan demikian dapat disimpulkan bahwa kondisi pertumbuhan ekonomi yang baik saja tidak cukup sebagai prasyarat untuk mengurangi tingkat kemiskinan.

Penelitian Irawadi (2018) aspek spasial memberikan pengaruh pada kemiskinan yang diperkuat oleh Nashwari (2016) menyebutkan bahwa aspek spasial kemiskinan memberikan pengaruh terhadap penyebaran kemiskinan petani tanaman pangan dan hasil perbandingan antara model kecamatan dengan model kabupaten ditemukan bahwa unit analisis kecamatan lebih variabel yang signifikan.

Penelitian Harmes at el. (2017) mengemukakan cluster kemiskinan yang dipetakan berdasar karakteristik pada masing-masing wilayah menggambarkan bahwa upaya penanggulangan kemiskinan harus berdasarkan pola spasial masingmasing wilayah dan penyeragaman kebijakan tanpa identifikasi spasial dapat memberikan dampak negatif dalam upaya penanggulangan kemiskinan.

Oleh karena itu, tujuan penelitian ini adalah (1) Menganalisis pola sebaran kemiskinan spasial secara umum maupun pada masing-masing unit wilayah (2) Menganalisis faktor-faktor yang mempengaruhi kemiskinan di Kabupaten Bandung Barat. Penelitian ini diharapkan dapat memberi manfaat dan kontribusi terhadap pertumbuhan dan pembangunan wilayah, terutama dalam penyusunan program anti kemiskinan khususnya daerah perdesaan. Penelitian ini juga diharapkan dapat dijadikan sebagai salah bahan evaluasi untuk pengambilan kebijakan dengan mempertimbangkan pola spasial atau lokasional dimana fenomena ini terjadi.

\section{METODE}

\section{LOKASI, PENGUMPULAN DATA DAN ANALISIS}

Lokasi penelitian dipilih secara sengaja sebagai tempat penelitian adalah Kabupaten Bandung Barat yang terdiri dari 16 kecamatan dan 165 desa. Jenis data yang digunakan dalam penenelitian ini adalah data sekunder pada tahun 2017 yang terdiri dari persentase jumlah penduduk miskin dan secara lebih rinci jenis dan sumber data akan dijelaskan pada Tabel 1 .

Tabel 1. Sumber Data

\begin{tabular}{l|l}
\multicolumn{1}{c|}{ Jenis Data } \\
$\begin{array}{l}\text { Persentase jumlah } \\
\text { penduduk miskin } \\
\text { Indeks Desa } \\
\text { Membangun }\end{array}$ & $\begin{array}{l}\text { Sumber Data } \\
\text { Dinas Sosial Kab. } \\
\text { Bandung Barat }\end{array}$ \\
\hline $\begin{array}{l}\text { Kumlah Penduduk, } \\
\text { Jarak Desa ke }\end{array}$ & $\begin{array}{l}\text { BPS Kab Bandung } \\
\text { Barat Dinas }\end{array}$ \\
$\begin{array}{l}\text { Ibukota Kabupaten, } \\
\text { Tingkat pendidikan, } \\
\text { persentase rumah } \\
\text { tangga pengguna }\end{array}$ & $\begin{array}{l}\text { Pemberdayaan } \\
\text { PLN dan Jumlah } \\
\text { Toko Kelontong } \\
\begin{array}{l}\text { Dana desa, Alokasi } \\
\text { dana desa }\end{array}\end{array}$ \\
\hline
\end{tabular}

Analisis data yang digunakan untuk mencapai tujuan penelitian ini adalah: pertama, analisis Moran (Indeks Moran) untuk menganalisis pola spasial kemiskinan secara umum di Kabupaten Bandung Barat, sedangkan untuk mengidentifikasi sebaran kemiskinan pada masing desa menggunakan uji LISA (Local Indicator of Spasial Autocorrelation). Kedua, untuk mengidentifikasi faktor -faktor yang mempengaruhi kemiskinan di Kabupaten Bandung Barat adalah dengan menggunakan teknik Ordinary Least Square (OLS).

Menurut Lee dan Wong (2001) uji Moran bertujuan untuk mengetahui dependensi spasial atau autokorelasi antar amatan atau lokasi atau dengan kata lain karakteristik suatu desa akan 
mempengaruhi (atau dipengaruhi) oleh karakteristik desa terdekat. Adanya autokorelai positif menunjukkan adanya kemiripan nilai dari lokasi-lokasi yang berdekatan dan cenderung berkelompok. Autokorelasi negatif menunjukkan lokasilokasi yang berdekatan mempunyai nilai yang berbeda dan cenderung berbeda.

Adapun rumus untuk menghitung autokorelasi spasial dengan menggunakan Indeks Moran sebagai berikut:

$$
\mathbf{I}=\frac{n \sum_{i=1}^{n} \sum_{j=1}^{n} w i j(x i-\bar{x})(x j-\bar{x})}{\sum_{i=1}^{n}(x i-\bar{x})^{2}}
$$

\section{Dimana:}

I : Indeks Moran

n : Banyaknya lokasi amatan (desa)

$x i$ : Nilai pada lokasi desa i

$x j \quad$ : Nilai pada lokasi desa $j$

$\bar{x} \quad$ : Nilai rata-tata dari xi dari n lokasi

wij : elemen pada pembobot terstandarisasi antara desa i dan j.

Hipotesis yang digunakan adalah,

pada tahap ini:

$\mathrm{Ho}=\mathrm{I}=\mathrm{I}_{0}$ (Tidak adanya autokorelasi spasial kemiskinan antar wilayah atau lokasi di setiap desa penelitian di Kabupaten Bandung Barat)

$\mathrm{Ha}=I \neq \mathrm{I}_{0} \quad$ (Adanya autokorelasi spasial kemiskinan antarwilayah atau lokasi di setiap desa di Kabupaten Bandung Barat)

Nilai ekspektasi dari uji Moran adalah:

$\mathrm{E}(I)=I_{0}=\frac{-1}{N-1}$

Terjadinya autokorelasi antar lokasi jika:

$Z_{\text {hitung }}=\frac{I-I o}{\sqrt{\operatorname{Var}(I)}} \sim N(0,1)$

Keterangan: I adalah koefisien Moran's I, Io adalah expected value Moran's I, dan var (I) adalah varians Moran's I. Pengambilan keputusan $\mathrm{H}_{0}$ ditolak jika $\left|Z_{\text {hitung }}\right|>Z_{\alpha / 2}$. Nilai I berada pada kisaran antara -1 dan 1 . Jika I $>$ Io maka nilai autokorelasinya positif, yang berarti pola data mengelompok (cluster), dan jika $\mathrm{I}<$ Io maka nilai autokorelasinya negatif yang menunjukkan pola data menyebar atau dispread.

\section{Local Indicator of Spatial Autocorrelation} (LISA)

Analisis LISA digunakan untuk mengidentifikasi dan mengelompokkan wilayah desa yang mililiki kemiripan yang nyata untuk tingkat kemiskinan atau pola spasial. Selain itu, uji LISA digunakan untuk mengetahui ketergantungan wilayah secara parsial, yang membedakannya dengan uji Moran adalah Moran hanya mengetahui tingkat ketergantungan wilayah secara menyeluruh. Analisis klasterisasi pola kemiskinan ini menggunakan Software GeoDa. Adapun pengelompokan tingkat kemiskinan desa dibagi menjadi 4 kuadaran yaitu Zhukov (2010) :

a. Kuadran I yaitu: High-high $(\mathrm{HH})$, pengelompokkan desa/kelurahan yang memiliki tingkat kemiskinan yang tinggi dikelilingi oleh desa/kelurahan dengan tingkat kemiskinan yang tinggi.

b. Kuadran II High-low (HL), desa dengan kemiskinan tinggi namun dikelilingi oleh desa atau kelurahan dengan kemiskinan rendah.

c. Kuadran III yaitu: Low-low (LL) mengelompokkan desa/kelurahan yang memiliki tingkat kemiskinan yang rendah dan dikelilingi oleh desa atau kelurahan dengan tingkat kemiskinan yang rendah pula.

d. Kuadran IV yaitu Low-high (LH), yaitu desa/kelurahan yang kemiskinan rendah dikelilingi oleh desa atau kelurahan dengan kemiskinan yang tinggi. Untuk lebih jelasnya dilihat Gambar 1.

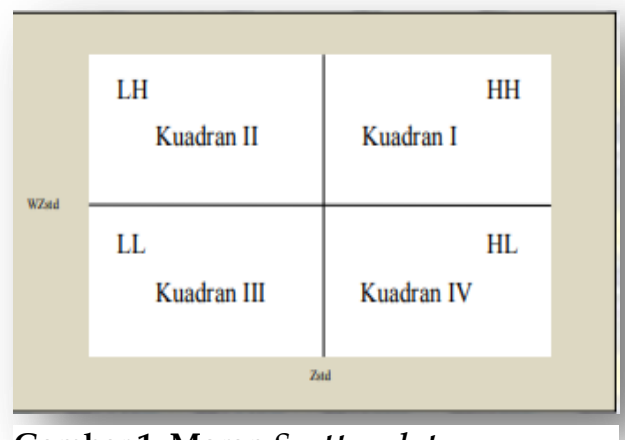

Gambar 1. Moran Scatter plot 


\section{Faktor-Faktor yang mempengaruhi kemiskinan di Kabupaten Bandung Barat}

Selanjutnya metode penelitian yang digunakan untuk menganalisis faktorfaktor kemiskinan adalah menggunakan pendekatan model regresi berganda dengan menggunakan metode Ordinary Least Square (OLS). Adapun model yang digunakan dalam penelitian ini adalah sebagai berikut:

Persentase Penduduk Miskin $=\mathrm{f}$ (Jumlah penduduk, Tingkat pendidikan diatas SMA, Jarak Desa ke Ibukota Kabupaten, Persentase Rumah Tangga pengguna PLN, Jumlah Toko Kelontong, Indeks Desa Membangun)

Model Persamannya sebagai berikut:

$$
\begin{aligned}
\mathrm{PPM}= & \alpha_{0}+\alpha_{1} \mathrm{JP}+\alpha_{2} \mathrm{TP}+\alpha_{3} \mathrm{ADD}+\alpha_{4} \mathrm{DD} \\
& +\alpha_{5} \mathrm{JTK}+\alpha_{6} \mathrm{IDM}+\alpha_{7} \mathrm{JD}+\alpha_{8} \mathrm{PLN}
\end{aligned}
$$

dimana,

$$
\begin{aligned}
& \text { PPM : Persentase Penduduk Miskin (\%) } \\
& \text { JP : Jumlah Penduduk (\%) } \\
& \text { TP : Tingkat pendidikan di atas SMA } \\
& (\%) \\
& \text { ADD Alokasi Dana Desa } \\
& \text { DD Dana Desa } \\
& \text { JTK Jumlah Toko Kelontong (unit) } \\
& \text { IDM Indeks Desa Membangun } \\
& \text { JD : Jarak Desa ke Ibukota Kabupaten } \\
& (\mathrm{Km}) \\
& \text { PLN : Persentase Rumah Tangga yang } \\
& \text { menggunakan PLN (\%) }
\end{aligned}
$$

\section{HASIL DAN PEMBAHASAN}

\section{Pola Sebaran Kemiskinan di Kabupaten Bandung Barat}

Salah satu cara untuk memberantas kemiskinan yang dapat dilakukan dengan mengetahui pola sebaran kemiskinan pada setiap daerah atau wilayah pengamatan. Wilayah dengan tingkat kemiskinan yang tinggi diduga dapat dipengaruhi oleh wilayah lain yang merupakan tetangganya yang memiliki tingkat kemiskinan yang tinggi. Analisis Indeks Moran digunakan untuk menganalisis adanya autokorelasi kemiskinan berdasarkan lokasi. Nilai dihasilkan pada perhitungan Indeks Moran berkisar antara $-1<$ I $<1$. Nilai ini biasanya dinyatakan dengan:

- $I_{0}=-1 / \mathrm{n}-1$ mendekati nol, tidak terdapat autokorelasi

- $I>I_{0}$, terdapat autokorelasi spasial positif dengan membentuk suatu pola data yang mengelompok (cluster).

- $I<\mathrm{I}_{0}$, terdapat autokorelasi spasial negatif yang menunjukkan pola data menyebar atau dispread.

Berdasarkan data persentase jumlah kemiskinan di 165 desa di Kabupaten Bandung Barat dapat diketahui pola penyebaran tingkat kemiskinannya pada Tabel 2.

Tabel 2. Indeks Moran

\begin{tabular}{|l|r|}
\hline Moran Index $(I)$ & 0,464173 \\
\hline Expected Index $\left(I_{0}\right)$ & $-0,006098$ \\
\hline Variace & 0,002535 \\
\hline Z-Sscore & 9,340340 \\
\hline P-value & 0,000000 \\
\hline
\end{tabular}

Sumber: Data diolah, 2019

Keterangan: nyata pada taraf 1 persen $(0,01)$

Tabel 2 menunjukkan bahwa nilai Indeks Moran sebesar 0,464173, dan Expected Index sebesar -0,006098, sehingga dapat disimpulkan bahwa terdapat autokorelasi spasial kemiskinan di setiap desa di Kabupaten Bandung Barat dengan pola sebarannya bersifat menggerombol/ mengelompok (clustered). Hal ini menjelaskan bahwa setiap desa memiliki pengaruh spasial yang kuat dalam mempengaruhi tingkat kemiskinannya. Desa-desa dengan kemiskinan yang tinggi akan mempengaruhi desa-desa yang lain yang menjadi tetangganya, begitu juga sebaliknya setiap desa yang memiliki tingkat kemiskinan yang rendah akan mempengaruhi desa yang menjadi tetangganya. Pola spasial kemiskinan hasil Indeks Moran di Kabupaten Bandung Barat ditunjukkan pada Gambar 2. 


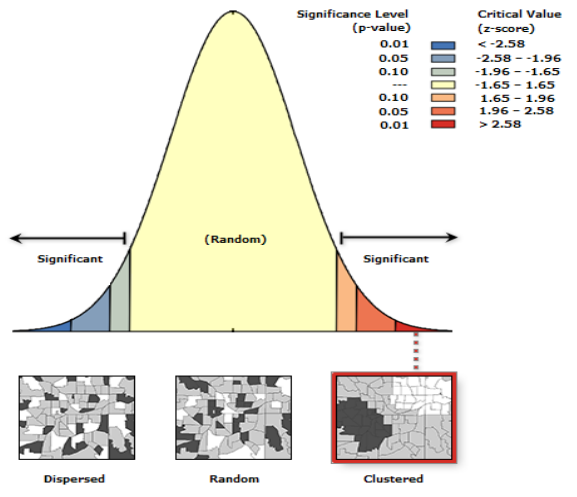

Gambar 2. Pola kemiskinan spasial secara umum di Kabupaten Bandung Barat

\section{Analisis Moran Lokal Anselin}

Hasil uji LISA digunakan untuk membuktikan bahwa terdapat dependensi spasial lokal untuk beberapa wilayah, sedangkan wilayah yang lain tidak signifikan. Dari 165 desa yang terdapat di Kabupaten Bandung Barat yang memiliki autokorelasi spasial lokal hanya 54 desa dengan tingkat signifikasi $1,0 \%$ sampai dengan $5,0 \%$. Untuk lebih jelasnya dapat dilihat pada Gambar 3.

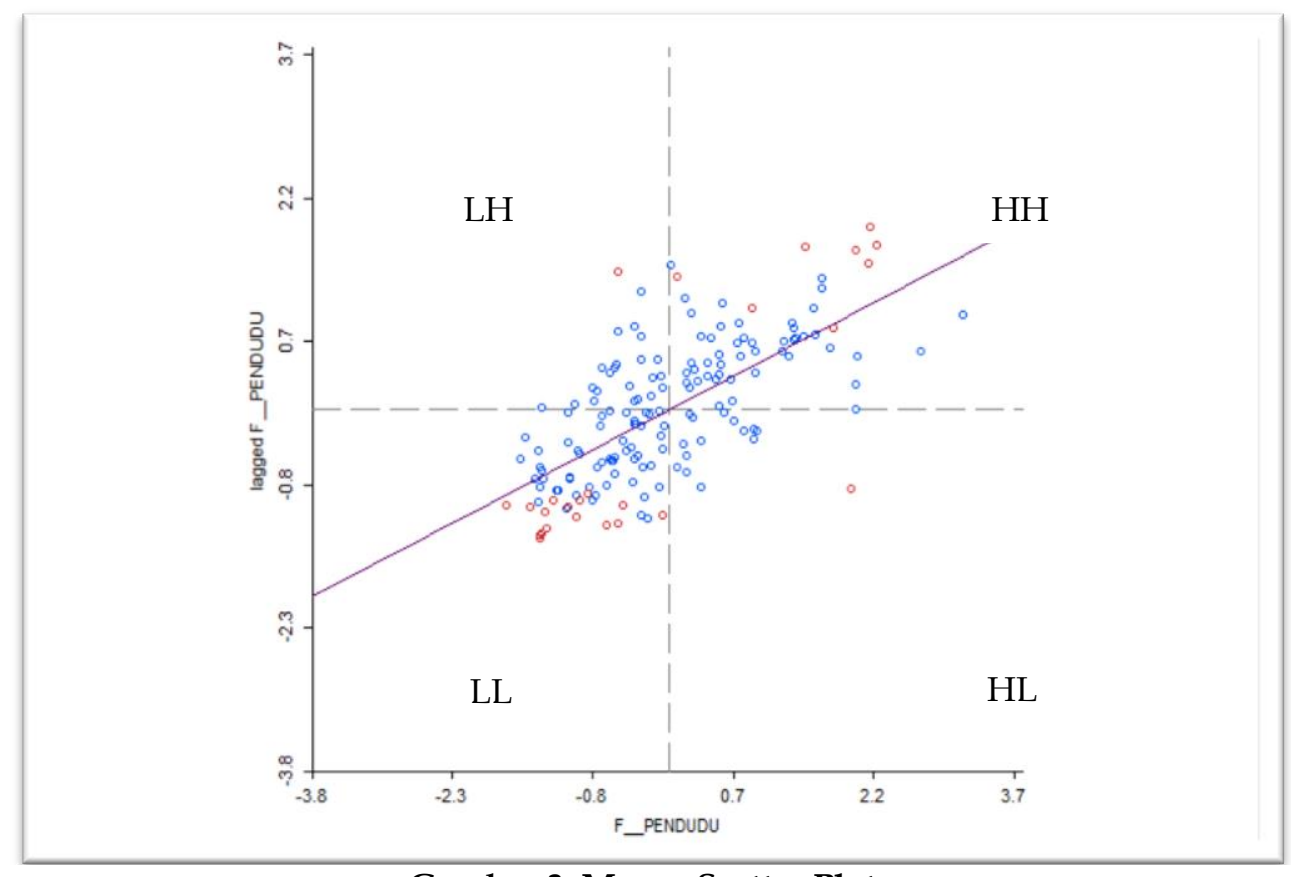

Gambar 3. Moran Scatter Plot

Selain melihat tingkat signifikasi desa-desa yang memiliki autokorelasi spasial lokal, selanjutnya adalah mengklasterisasikan desa-desa yang masuk dalam kriteria kemiskinan Tinggi-tinggi (high-high), kemiskinan rendah dikelilingi oleh kemiskinan rendah (low-low), kemiskinan tinggi dikelilingi oleh kemiskinan rendah (high-low) dan kemiskinan rendah dikelilingi oleh kemiskinan tinggi (low-high). Pada Tabel 3 dapat dilihat bahwa pengelompokkan spasial berdasarkan tingkat kemiskinan di
Kabupaten Bandung Barat terdiri dari 4 kelompok yakni sebanyak 17 desa yang berada pada kriteria high-high, 31 desa/kelurahan berada pada kriteria lowlow, 5 desa pada kriteria low-high dan 1 desa berada pada kriteria high-low. Salah satu tujuan pengujian ini untuk mempermudah pengambilan kebijakan dalam suatu wilayah, sehingga penanganannya tepat pada wilayah yang menjadi kantongkantong kemiskinan. 
Tabel 3. Pengelompokan Kemiskinan di Kabupaten Bandung Barat

\begin{tabular}{|c|c|c|c|}
\hline Tinggi-tinggi & Rendah-rendah & Rendah-Tinggi & Tinggi-Rendah \\
\hline 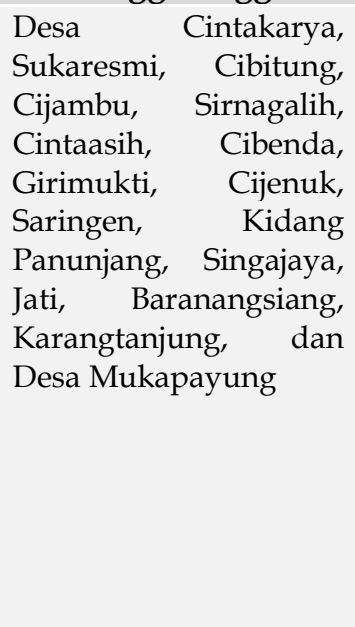 & 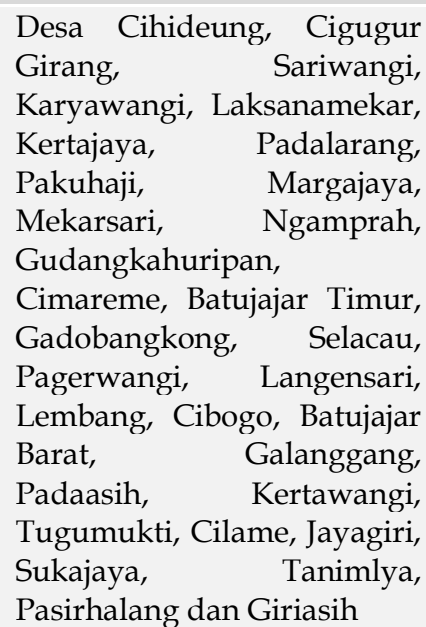 & $\begin{array}{lr}\text { Desa } & \text { Cicangkang } \\
\text { Girang, Karangsari, } & \text { Kajamandala } \\
\text { Rulon, } \\
\text { Ciptaharja } \\
\text { Mekarsari }\end{array}$ & $\begin{array}{l}\text { Desa } \\
\text { Bojongkoneng }\end{array}$ \\
\hline
\end{tabular}

Desa yang masuk dalam kategori tingkat kemiskinan tinggi dikelilingi oleh desa dengan kemiskinan tinggi di Kabupaten Bandung Barat disebabkan karena beberapa hal salah satunya aspek jarak atau lokasi. Desa-desa dengan kemiskinan tinggi umumnya memiliki jarak desa yang cukup jauh dari ibukota kabupaten, atau letaknya jauh dari pusatpusat ekonomi di Kabupten Bandung Barat, sehingga menyebabkan terlambatnya interaksi penduduk dalam kegiatan ekonominya dan membutuhkan waktu tempuh yang lama, dan masyarakat tidak mempunyai jalan alternatif untuk memasarkan hasil produknya agar lebih cepat, untuk lebih jelasnya dapat dilihat pada Gambar 4.

Desa yang termasuk dalam kategori kemiskinan rendah dikelilingi oleh kemiskinan rendah (low-low), terdapat beberapa penyebab salah satu akses jalan yang sangat baik, memiliki alternatif jalan yang cukup banyak karena lokasi yang dekat dengan ibukota Kabupaten maupun Kota Bandung sebagai salah satu pusat pertumbuhan Provinsi Jawa Barat, sehingga interaksi penduduk pada pusat kegiatan perekonomian lebih mudah.

Wilayah yang termasuk dalam kategori low-high, dimana desa yang tingkat kemiskinannya rendah dikelilingi oleh desa dengan kemiskinan yang tinggi. Wilayah ini diduga layak dijadikan sebagai desa percontohan karena desa-desa disekitarnya atau yang menjadi tetangganya adalah wilayah dengan tingkat kemiskinan tinggi. Namun daerah ini juga harus menjadi pusat perhatian pemerintah agar daerah ini tidak mengikuti tetangganya.

Desa yang termasuk dalam kategori High-low, yaitu desa-desa dimana tingkat kemiskinan tinggi dikelilingi oleh desa dengan kemiskinan rendah. Wilayah yang termasuk dalam kategori high-low ini memerlukan sinergitas kebijakan antar program di wilayah yang berdekatan dan kerjasama antar daerah dalam kawasan agar dapat mengikuti tetangganya. Salah satu penyebabnya adalah wilayah ini merupakan daerah pinggiran kota, atau wilayah suburban. Pengelompokan wilayah berdasarkan kategori kemiskinan dapat dilihat pada Gambar 4. Menurut Kolopaking (2011) kerjasama dapat berupa: kerjasama antar desa dalam satu kecamatan untuk meningkatkan efektivitas dan efisiensi playanan publik dan pembangunan, kerjasama antar desa antar kecamatan untuk memperjuangkan kepentingan bersama antar desadan kecamatan yang berbatasan. Kerjasama dapat dilakukan dengan (1) pengembangan potensi ekonomi dan sumberdaya kawasan, (2) penguatan kapasitas lembaga ekonomi dan Bumdes , (3) peningkatan infrastruktur dasar dan ekonomi desa. 


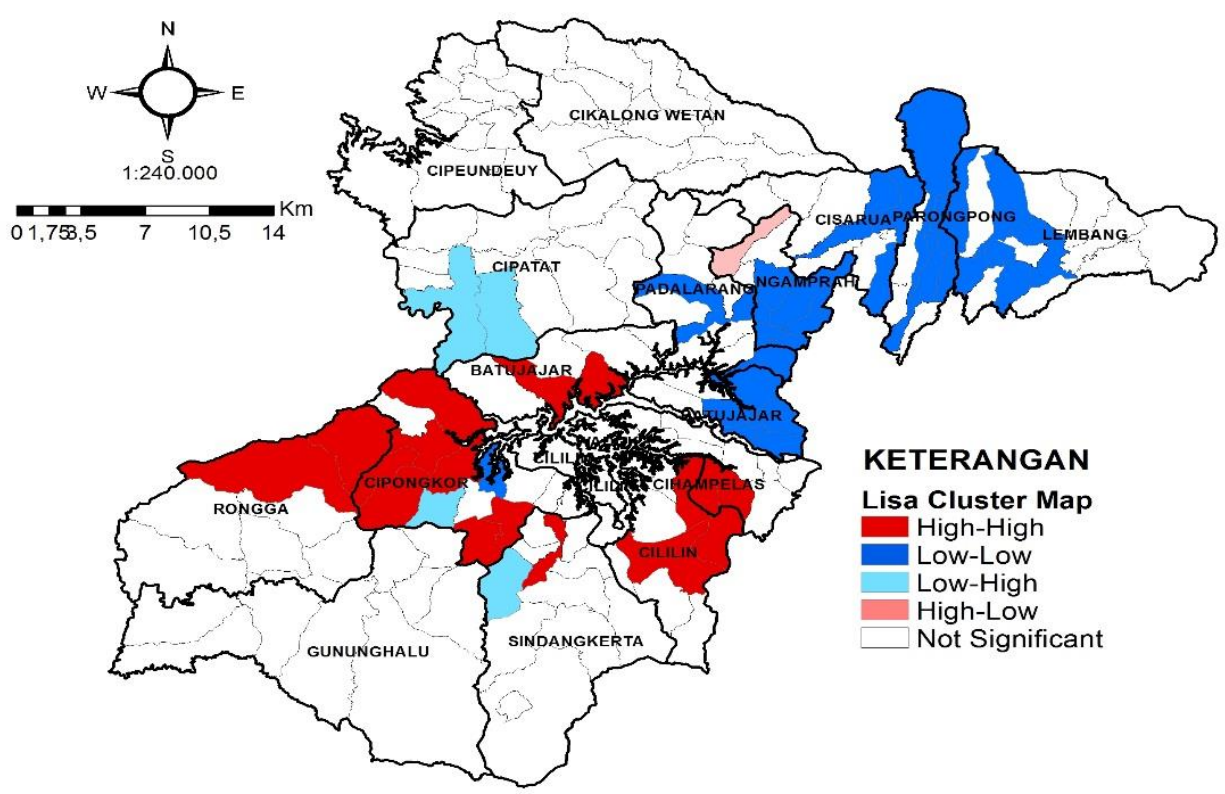

Gambar 4. Peta Klaster wilayah yang memiliki autokorelasi spasial lokal

Adanya pengelompokkan dan konsentrasi pola spasial kemiskinan di Kabupaten Bandung Barat diharapkan bahwa kebijakan dalam menurunkan kemiskinan sebaiknya diproritaskan pada wilayah-wilayah yang merupakan kantong kemiskinan tinggi. Dengan kata lain kemiskinan yang tinggi harus dilihat berdasarkan kondisi tetangga disekelilingnya sehingga penetapan lokus target dalam penanggulangan kemiskinan akan menjadi semakin mendekati riil pada desa masing-masing (Harmes, 2017).

Adanya Cluster kemiskinan yang dipetakan berdasarkan kondisi karakteristik wilayah desa masing-masing menandakan bahwa kebijakan penanggulangan kemiskinan harus memperhatikan pola spasial. Penyeragaman pengambilan kebijakan tanpa adanya identifkasi pola kemiskinan spasial akan berdampak pada kebijakan yang tidak sesuai dengan desa yang satu dengan lainnya, sehingga memberikan dampak negatif pada tujuan penanggulangan tingkat kemiskinan. Sebaliknya pemetaan spasial kemiskinan merupakan peluang dan tantangan untuk mendorong lahirnya kebijakan, rencana, dan program penanggulangan kemiskinan. Harmes et al. (2017) mengemukakan adanya heterogenitas karakteristik kemiskinan menunjukkan bahwa pendekatan program dan kebijakan penanggulangan kemiskinan harus bervariasi sesuai dengan kekhasan daerah masing-masing.

\section{Faktor-faktor yang memengaruhi kemiskinan di Kabupaten Bandung Barat}

Setelah mengetahui kantongkantong kemiskinan, maka langkah selanjutnya adalah identifikasi faktor-faktor yang mempengaruhi kemiskinan di Kabupaten Bandung Barat dengan menggunakan analisis linier regresi berganda. Adapun persamaan model regresi linier dalam penelitian ini adalah:

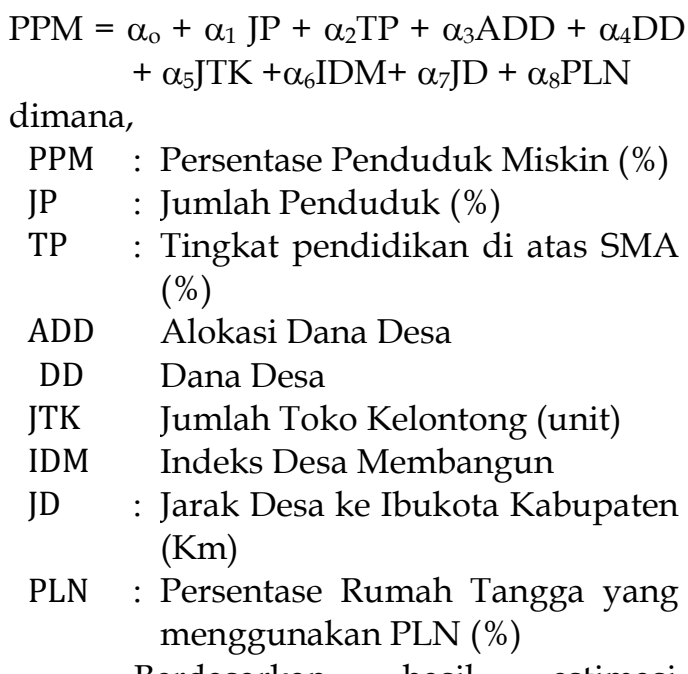
diperoleh nilai $R$-Square $\left(\mathrm{R}^{2}\right)$ estimasi, persen. Nilai $R$-Square $\left(R^{2}\right)$ menjelaskan bahwa variasi nilai variabel $\mathrm{Y}$ dapat 
dijelaskan model sebesar 81,02 persen. Hal ini berarti variabel kemiskinan di Kabupaten Bandung Barat dapat dijelaskan oleh faktor jumlah penduduk, tingkat pendidikan di atas SMA, alokasi dana desa, dana desa, jumlah toko kelontong, indeks desa membangun, jarak desa ke ibukota kabupaten, rumah tangga yang menggunakan PLN sebesar 81,02 selebihnya 19,08 dijelaskan oleh faktor lain yang tidak dimasukkan dalam model penelitian. Untuk lebih jelasnya dapat dilihat pada Tabel 4.

Tabel 4. Hasil Analisis Regresi

R-squared=0,8102 $\mathrm{N}=165$

Adjusted R-squared $=0,800513$

T-Stat $=83.26362$

Prob(F-statistic $)=0,00000$

S.E. of regression $=0,318909$

\begin{tabular}{|l|c|c|c|c|}
\hline variabel & coefficient & $\begin{array}{c}\text { Std. } \\
\text { Error }\end{array}$ & T-Stat & Prob. \\
\hline C & 1739,77 & 227,50 & 7,65 & $0,000^{*}$ \\
\hline JP & $-1,295$ & 0,089 & $-14,59$ & $0,000^{*}$ \\
\hline TP & $-0,0423$ & 0,025 & $-1,689$ & $0,093^{* *}$ \\
\hline ADD & -1187.279 & 141.77 & -8.375 & $0,000^{*}$ \\
\hline DD & 1102.25 & 130,58 & 8,441 & $0,000^{*}$ \\
\hline JTK & -0.865 & 0,286 & $-3,023$ & $0,003^{*}$ \\
\hline IDM & -0.0082 & 0,018 & 0,446 & 0,6559 \\
\hline JD & -0.0041 & 0,044 & 0,0936 & 0,9256 \\
\hline PLN & 0.0470 & 0,032 & 1,448 & 0,1496 \\
\hline
\end{tabular}

Sumber: Data Diolah

Keterangan *) Nyata pada taraf 1 persen $\left.(0,01),{ }^{* *}\right)$ Nyata pada taraf 10 persen $(0,10)$

Tabel 4 menunjukkan jumlah variabel yang signifikan dalam menurunkan kemiskinan pada tingkat signifikasi pada 5 persen dan 10 persen adalah jumlah penduduk, tingkat pendidikan, alokasi dana desa, dana desa dan jumlah toko kelontong, sedangkan variabel yang tidak signifikan adalah variabel indeks desa membangun, jarak desa keibukota kabupaten dan jumlah masyarakat pengguna listrik. Berikut penjelasan masing-masing variabel yang dibangun dalam penelitian ini:

1. Pengaruh Jumlah penduduk terhadap kemiskinan.

Jumlah penduduk memiliki pengaruh negatif terhadap kemiskinan di Kabupaten Bandung Barat dengan probabilitas sebesar 0,0000 dan koefisien regresi sebesar -1,295. Besaran koefisien yang bernilai negatif menandakan bahwa penambahan jumlah penduduk menurunkan kemiskinan. Hal ini dikarenakan karena penduduk Kabupaten Bandung Barat sebagian besar berada pada usia kerja dengan umur 15-64 tahun sebesar 67,88 persen. Jika dilihat dari angkatan kerja sebanyak 645.345 penduduk (45,24 persen) sudah bekerja, dan yang mencari pekerjaan sebesar 50,985 penduduk $(3,57)$ dan hampir 53 persen tingkat pendidikan yang mencari pekerjaan adalah SMA (Kab. Bandung Barat dalam Angka 2018). Dengan demikian penambahan jumlah penduduk diduga mampu memacu pembangunan di Kabupaten Bandung Barat. Hal ini sejalan dengan penelitian Astuti (2015) yang mengemukan bahwa jumlah penduduk yang besar adalah potensi pasar dan menjadi sumber permintaan akan barang dan jasa yang akan menggerakkan berbagai sektor perekonomian sehingga menciptakan skala ekonomi dalam produksi yang tinggi dan pada akhirnya akan meningkatkan output atau produksi agrigat yang lebih tinggi. Dengan demikian pertambahan jumlah penduduk tanpa diimbangi dengan kualitas sumber daya manusia akan menyebabkan permasalahan kemiskinan, namun sebaliknya jika pertambahan penduduk diimbangi dengan peningkatan kualitas sumberdaya manusia akan meningkatkan perekonomian.

\section{Pengaruh Tingkat Pendidikan terhadap Kemiskinan}

Tingkat pendidikan memiliki pengaruh negatif terhadap kemiskinan di Kabupaten Bandung Barat dengan probabilitas sebesar 0,0932 dan koefisien regresi sebesar $-0,0423$. Besaran koefisien yang bernilai negatif menandakan bahwa semakin tinggi tingkat pendidikan dapat menurunkan tingkat kemiskinan. Tingkat pendidikan masyarakat di Kabupaten Bandung Barat sebagian besar adalah sekolah dasar 35,91 persen, SMP sebesar 23,64 dan tingkat pendidikan masyarakat di atas SMA hanya sebesar 5,01 persen. Untuk lebih jelasnya dapat dilihat pada Gambar 5 . Sumber: BPS Kab. Bandung Barat 2017 


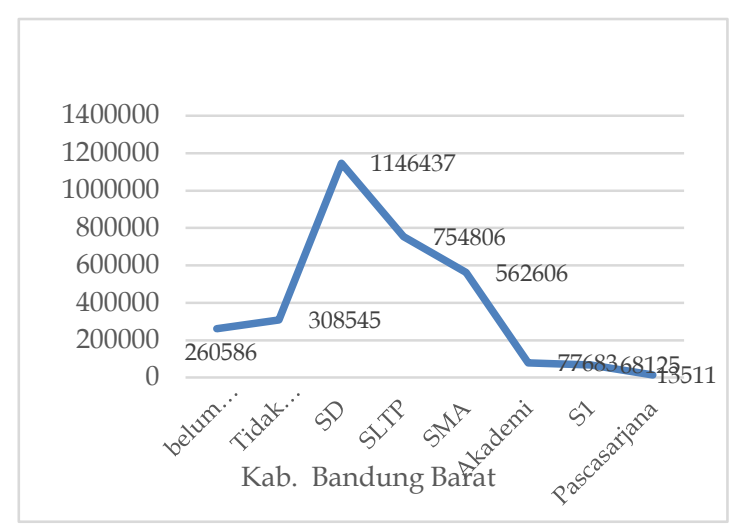

Gambar 5. Tingkat pendidikan masyarakat

Penelitian Annur (2013) mengemukakan bahwa tingkat pendidikan yang rendah menyebabkan masyarakat memiliki keterampilan yang rendah, sehingga menyebabkan keterbatasan dalam dunia kerja dan meningkatkan tingginya angka kemiskinan. Rendahnya pendidikan masyarakat di Kabupaten Bandung Barat harus menjadi perhatian serius pemerintah daerah, terutama jenjang pendidikan yang lebih tinggi. Capra (2009) mengemukakan meningkatkan jenjang pendidikan merupakan salah satu cara untuk menanggulangi tingkat kemiskinan.

\section{Pengaruh Alokasi Dana Desa terhadap} Kemiskinan

Alokasi dana desa (ADD) memiliki pengaruh negatif terhadap kemiskinan di Kabupaten Bandung Barat dengan probabilitas sebesar 0,0000 dan koefisien regresi sebesar -1187.279. Hal ini berarti alokasi dana desa mampu menurunkan tingkat kemiskinan di Kabupaten Bandung Barat. Alokasi dana desa (ADD) adalah adalah dana perimbangan yang diterima kabupaten/kota dalam Anggaran Pendapatan dan Belanja Daerah kabupaten/kota setelah dikurangi Dana Alokasi Khusus. Besar kecilnya alokasi dana desa 10 persen dari dana perimbangan yang diterima daerah dalam

APBD setelah dikurangi Dana Alokasi Khusus. Sedangkan besaran ADD di setiap desa ditentukan berdasarkan jumlah penduduk, luas wilayah, angka kemiskinan, dan kesulitan geografis

(Perbub Kab. Bandung Barat no 7 tahun 2017 tentang Alokasi dan Pembagian ADD). Adapun perkembangan anggaran alokasi dana desa tahun 2015-2017 adalah
108.819 juta rupiah, 118.326 juta rupiah dan 115.963 juta rupiah.

Alokasi dana desa digunakan untuk pembelanjaan bidang pembangunan infrastruktur desa, belanja operasional desa, belanja pemberdayaan masyarakat desa dan belanja pembinaan masyarakat desa. Jika dilihat dari serapan dan efektivitas penggunaan anggaran alokasi dana desa di Kabupaten Bandung Barat untuk masing-masing bidang belanja desa sebagai berikut: bidang pembangunan infrastruktur desa sebesar 98,65 persen anggaran efektif digunakan, bidang operasional pemerintah desa sebesar 98,39 persen anggaran efektif, bidang pemberdayaan masyarakat desa sebesar 93,54 persen anggaran efektif dan bidang pembinaan masyarakat desa sebesar 97,57 persen anggran efektif. Hal inilah yang diduga bahwa alokasi dana desa mampu menurunkan kemiskinan di Kabupaten bandung Barat. Hal ini sejalan dengan penelitian Prasetyanto dan Eko (2012) yang mengemukakan bahwa penyaluran ADD yang benar sesuai dengan arahan maka meningkatkan kinerja fiskal daerah maka akan mampu mengurangi jumlah penduduk miskin.

\section{Pengaruh Dana Desa terhadap Kemiskinan}

Dana desa (DD) memiliki pengaruh positif terhadap kemiskinan di Kabupaten Bandung Barat dengan probabilitas sebesar 0,0000 dan koefisien regresi sebesar 1102.25. Artinya semakin tinggi dana desa maka kemiskinan di Kabupaten Bandung Barat juga tinggi, atau dana desa belum mampu mereduksi tingkat kemiskinan. dana desa yang masuk dalam kas desa digunakan untuk dua hal yakni untuk bidang pembangunan dan bidang pemberdayaan masyarakat. Saat ini penggunaan dana desa sebagian besar digunakan untuk bidang pembangunan desa. Hal ini sejalan dengan penelitian artino (2017) yang mengemukakan dana desa di Kabupaten Lombok belum berpengaruh secara signifikan terhadap kemiskinan, karena sebagian besar anggaran dana desa digunakan untuk pembangunan infrastruktur desa. Kabupaten Bandung Barat total dana yang diterima pada tahun 2017 sebesar besarnya Rp 152.336 juta 
rupiah dan dana desa yang digunakan untuk bidang pembangunan adalah Rp. 135.269 juta rupiah $(91,24)$ persen sedangkan untuk bidang pemberdayaan masyarakat hanya sebesar 13.111 juta rupiah $(9,30)$ persen dari total anggaran. Artinya dana desa yang sebagian besar digunakan untuk pembagunan infrastruktur yang dalam kurun waktu lima tahun (jangka pendek) belum mampu dirasakan manfaatnya oleh masyarakat. Pembangunan infrastruktur ini akan dirasakan manfaatnya dalam jangka panjang, sehingga seiring dengan berjalannya waktu dan perbaikan kualitas belanja desa maka perekonomian desa akan semakin baik. Adapun program bidang pembangunan desa di Kabupaten Bandung Barat secara umum adalah pembangunan dan pemeliharaan jalan desa, pembangunan dan pemeliharaan jalan lingkungan, pembangunan sanitasi lingkungan, pengelolaan air berskala desa, pengelolaan BUMDes danlain-lain.

\section{Pengaruh Toko Kelontong terhadap Kemiskinan}

Toko Kelontong memiliki pengaruh negatif terhadap kemiskinan di Kabupaten Bandung Barat dengan probabilitas sebesar 0,0029 dan koefisien regresi sebesar -0.865 . hal ini berarti semakin banyak toko kelontong di Kabupaten Bandung Barat diduga mampu menurunkan tingkat kemiskinan. Akan tetapi, jumlah koto kelontong mengalami penurunan seiring berjannya waktu, adapun salah satu penyebabnya adalah kemunculan banyaknya toko-toko modern. Untuk lebih jelas dapat dilihat pada Gambar 6 .

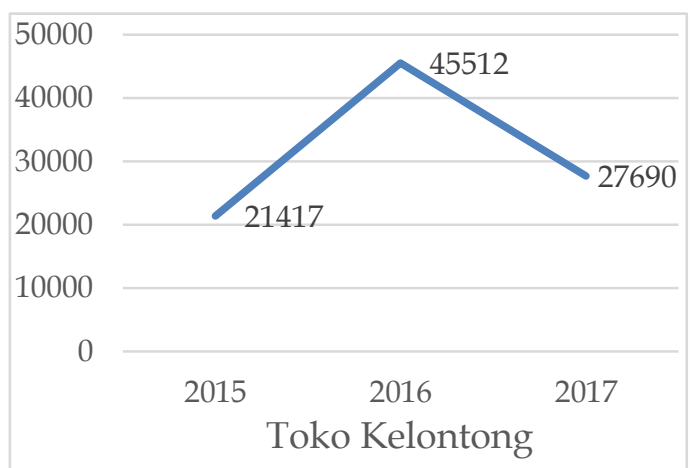

Gambar 6. Jumlah toko kelontong di Kab. Bandung Barat

Sumber: BPS Kab Bandung Barat 2017
Gambar 6 menunjukkan bahwa perkembangan toko kelontong di Kab. Bandung Barat. Pada tahun 2017 terjadi penurunan jumlah toko kelontong yang sangat signifikan yakni sebesar 39,16 persen. Jika hal ini tidak ditanggulangi dengan cepat maka lama-kelaman toko kelontong ini akan kalah bersaing dengan toko-toko modern. Menurun Sitepu (2011) kehadiran pasar modern memberikan pengaruh negatif bagi perkembangan UMKM terhadap sektor perdagangan.

\section{Pengaruh IDM dalam menurunkan kemiskinan}

Indeks desa membangun memiliki pengaruh negatif terhadap kemiskinan di Kabupaten Bandung Barat dengan probabilitas 0,6559 sebesar dan koefisien regresi sebesar -0.0082. IDM memiliki pengaruh yang negatif terhadap kemiskinan namun probabilitasnya sangat besar. Tujuan adanya IDM adalah untuk meningkatkan desa mandiri. Semakin tinggi nilai indeks mka semakin jauh ratarata pengeluaran penduduk miskin dari garis kemiskinan (Kemendes PDTT). Jika dilihat dari angka Indeks Desa membangun dari total 165 desa yang terdapat di Kabupaten Bandung Barat masih terdapat 24,84 persen (41) Desa berstatus tertinggal, 3 desa berstatus sangat tertinggal, 50,30 persen (83) desa berstatus desa berkembang, 20,60 persen (34) desa berstatus desa maju dan 4 desa berstatus desa mandiri.

7. Pengaruh Jarak Desa ke Ibukota Kabupaten terhadap kemiskinan

Jarak desa memiliki pengaruh negatif terhadap kemiskinan di Kabupaten Bandung Barat dengan probabilitas 0,9256 sebesar dan koefisien regresi sebesar 0.0041, namun tidak signifikan. Hal ini karena Kabupaten Bandung Barat adalah Kabupaten yang lebih dekat dengan ibukota provinsi Jawa Barat yaitu Kota Bandung yang merupakan salah satu pusat pertumbuhan ekonomi Provinsi Jawa Barat. kemungkinan aktivitas perekonomian wilayah.

8. Pengaruh Masyarakat yang menggunakan Listrik PLN terhadap Kemiskinan 
Masyarakat yang menggunakan Listrik PLN memiliki pengaruh positif terhadap kemiskinan di Kabupaten Bandung Barat dengan probabilitas sebesar 0,1496 dan koefisien regresi sebesar 0.0470 . Hal ini berarti jumlah masyarakat yang menggunakan listrik PLN tidak berpengaruh terhadap kemiskinan, hal ini dikarenakan karna hampir 95 persen masyarakat Kabupaten Bandung Barat telah menggunakan listrik dalam aktivitas sehari-hari.

\section{KESIMPULAN DAN SARAN}

\section{KESIMPULAN}

Pola sebaran kemiskinan di setiap desa di Kabupaten Bandung Barat bersifat mengelompok (clustered) yang dipetakan ke dalam empat kategori wilayah yakni sebanyak 17 desa yang berada pada kategori desa dengan kemiskinan tinggi dikelilingi oleh desa kemiskinan tingg (high-high), 31 desa/kelurahan berada pada kriteria desa kemiskinan rendah dikelilingi oleh desa dengan kemiskinan rendah (lowlow), 5 desa pada kriteria desa kemiskinan rendah dikelilingi oleh desa dengan kemiskinan tinggi (low-high) dan 1 desa berada pada kriteria desa dengan kemiskinan tinggi dikelilingi oleh densa dengan kemiskinan rendah (high-low). Adapun faktor-faktor yang mempengaruhi kemiskinan di Kabupaten Bandung Barat adalah jumlah penduduk terbukti cenderung berpengaruh positif terhadap kemiskinan, tingkat pendidikan cenderung berpengaruh negatif terhadap kemiskinan, alokasi dana desa cenderung berpengaruh negatif terhadap kemiskinan, jumlah toko kelontong juga berpengaruh negatif terhadap kemiskinan dengan tingkat kepercayaan $5 \%$ dan $10 \%$.

\section{SARAN}

Pengambilan kebijakan penanganan kemiskinan perlu mempertimbangkan aspek lokasi sampai kepada unit terkecil agar mampu memberikan gambaran secara akurat mengenai variasi kemiskinan dan kesesuaian program. Penanganan kemiskinan lebih difokuskan pada wilayahwilayah dengan tingkat kemiskinan yang tinggi dengan memperhatikan kesesuaiam target dan program yang tepat sesuai dengan lokasi masing-masing. Adanya heterogenitas wilayah yang berbeda-beda maka menunjukkan pendekatan program kemiskinan harus bervariasi sesuai dengan kekhasan masing-masing desa.

\section{DAFTAR PUSTAKA}

Annur RA. 2013. Faktor-faktor yang Mempengaruhi Kemiskinan di Kecamatan Jekulo dan Mejobo Kabupaten Kudus. Economics Development Analysis Journal: Vol 2 (4).

Astuti RR. 2015. Analisis Pengaruh Jumlah Penduduk, Pertumbuhan Ekonomi, Pendidikan dan Kesehatan terhadap Jumlah Penduduk Miskin Di Indonesia Tahun 2004-2012. [Skripsi] Yogyakarta (ID): Universitas Negeri Yogyakarta.

Artino, Adi. 2017. Keterkaitan Dana Desa terhadap Kemiskinan di Kabupaten Lombok Utara [Tesis]. Bogor (ID): Institut Pertanian Bogor.

[BPS] Badan Pusat Statistika. 2018. Persentase Penduduk Miskin menurut Perkotaan dan Perdesaan di Indonesia Tahun 2017.

[BPS] Badan Pusat Statistika Provinsi Jawa Barat. 2018. Indeks kedalaman dan Keparahan Kemiskinan Kabupaten Bandung Barat Tahun 2017. Kabupaten Bandung Barat (ID): BPS.

[BPS] Badan Pusat Statistika kabupaten Bandung Barat. 2018. Persentase kemiskinan Kabupaten Bandung Barat Tahun 2014-2019. Kabupaten Bandung Barat (ID): BPS.

Capra T. 2009. Poverty and its Impact on education: Today and Tomorrow. The new Higher Education Journal.

Harmes, Juanda B, Rustiadi E dan Barus B. 2017. Pemetaan Efek Spasial Pada Data Kemiskinan Kota Bengkulu. Journal of Regional and Rural Development Planning, Vol 1 (2):192201 
Hikmat, H. 2004. Strategi Pemberdayaan Massyarakat. Penerbit Humaniora. Bandung.

Irawadi A. 2018. Analisis Kemiskinan Spasial dan Kaitannya dengan Sertifikasi Tanah dan Penggunaan Lahan Pertanian di Kabupaten Mamuju. [tesis.] Bogor (ID): Institut Pertanian Bogor.

Kolopaking LM. 2011. Peningkatan dan Penguatan Struktur Kelembagaan Desa. Menuju Desa 2030. Bogor (ID): Cresrpent Press.

Lee, J., Wong, D.W.S. 2001. Statistical Analysis ArcView GIS. New York: John Wiley \& Sons, Inc

Nashwari IP. 2016. Analisis Kemiskinan Petani Tanaman Pangan di Provinsi Jambi dan Jawa Barat menggunakan Geographically Weighted Regression [disertasi]. Bogor (ID): Institut Pertanian Bogor.

Nasution MZ, 2008. Farm Poverty and Rural Poverty in Kulon Progo Regency Indonesia. [internet]. diunduh 27 Oktober 2015. Tersedia dihttps://mpra.ub.unimuenchen.de/9963/1/MPRA_paper _9963.pdf

Nugraha JT, Sari EDR. 2016. Membangun Indonesia dari Pinggiran melalui Kegiatan Fasilitasi Daerah dalam Penetapan Kawasan Perdesaan Mandiri Pangan untuk Memperkuat Daerah dan Desa di kabupaten Klaten. [internet]. [Diunduh pada tanggal 16 juni 2019]. http:/ / fisipol.untidar.ac.id/wpcontent/uploads/2016/10/FasilitasiPemerintah-Daerah-DalamPenetapan-Kawasan-PerdesaanMandiri-Pangan-Di-KabupatenKlaten.pdf.

Prasetyanto PP, dan Eko. 2012 Dampak Alokasi Dana Desa Pada Era Desentralisasi Fiskal Terhadap Perekonomian Daerah Di Indonesia.
[Disertasi]. Bogor (ID) Institut Pertanian Bogor.

Rustiadi E, Saefulhakim S, Panuju DR. 2008. Perencanaan Pengembangan Wilayah . Bogor. Crespent Press \$ Yayasan Obor Indonesia.

Sajogyo. 1987. Ekologi Pedesaan, Sebuah Bunga Rampai. Jakarta (ID): Rajawali Pres.

Syafitri UD, Bagus S, Salamatuttanzil. 2008. Pengujian Autokorelasi terhadap Sisaan Model Spatial Logistik. Makalah Seminar Nasional Matematika dan Pendidikan Matematika. Yogyakarka (ID): Universitas Negeri Yogyakarta. 